How to Cite

Primatanti, P. A., \& Jawi, I. M. (2019). Anthocyanin as neuroprotector for methamphetamine-induced neurotoxicity. International

Journal of Health \& Medical Sciences, 3(1), 11-16. https://doi.org/10.31295/ijhms.v3n1.101

\title{
Anthocyanin as Neuroprotector for Methamphetamine-Induced Neurotoxicity
}

\author{
Putu Asih Primatanti \\ Udayana University, Denpasar, Indonesia \\ Corresponding author email: dr.asih@gmail.com
}

I Made Jawi

Udayana University, Denpasar, Indonesia

\begin{abstract}
Methamphetamines are chemicals that might affect brain function and causes the development of addiction and other brain pathologies. It increased dopamine stimulation and would increase the formation of free radicals leading to dopaminergic neurotoxicity. Various therapeutic targets have been developed to prevent or minimize the negative effects of methamphetamine use. Increased level of oxidative stress has been considered as a potential trigger for neurotoxicity hence the expected ability for the administration of antioxidants to prevent damages caused by free radicals. The administration of antioxidants is expected to provide protective effects and prevent further damages created by methamphetamine exposure. Anthocyanin is a type of flavonoid is a potentially effective neuroprotector candidate for preventing neuronal cell death reduction, and this compound works with various mechanisms.
\end{abstract}

Keywords---anthocyanin, methamphetamine, neurotoxicity, neuroprotector.

\section{Introduction}

Drug and substance abuse has continuously become a significant global social issue. To date, the scale of the prevalence of drug and substance abuse worldwide is estimated to be $0.6 \%$ of the world adult population or equals about 29.5 million people (UNODC, 2017). This abuse has led to dependence or addiction that might cause both physical and mental effects, and even neurotoxicity or damages in the central nervous system (Sharma et al., 2014; Lu R et al., 2017; Allan et al., 2016).

Psychostimulant substances including methamphetamines are chemicals that might affect the brain function and causes the development of addiction and other brain pathologies (Sharma et al., 2014; Krasnova et al., 2016). Long term and high dose short term use of methamphetamine could cause neurotoxic effect and incite several observable neurochemical changes, both in humans and animals. These changes are commonly found in striatum (caudate nucleus-putamen), hypothalamus, thalamus, cortex, and hippocampus (Yamada, 2008; Chen et al., 2014; Salamanca et al., 2015; Volkow et al., 2015; Heinsleigh, 2017). The occurring significant and persistent changes in the transporter, receptor, or enzyme levels are observed during the withdrawal phase and they signify several fundamental changes in the neurons. This abnormal condition contributes to the development of the brain pathology of addiction (Volkow, 2015; Koob, 2009; Dewi \& Mustika, 2018).

During methamphetamine administration, the increased dopamine stimulation would increase the formation of free radicals leading to dopaminergic neurotoxicity. Subsequently, persistent deficits of dopamine, tyrosine hydroxylase protein, and dopamine transporter (DAT) levels might follow (Wu et al., 2006; McFadden \& VieiraBrock, 2016). In mice provided with $10 \mathrm{mg} / \mathrm{kg}$ methamphetamines four times, decreased levels of dopamine, tyrosine hydroxylase activity, and DAT was evident, as well as the decreased VMAT bonding in the striatum after 24 hours. The decrease or loss of dopamine markers shortly thereafter has been correlated with the process of neuronal degeneration leading to the loss of neuronal components, which has been proposed as a histological marker of

ISSN 2632-9433

Received Jul 18, 2019 / Accepted Sept 09, 2019 / Published Sept 17, 2019 
neuronal damages and behavioral abnormalities (Moszczynska \& Yamamoto, 2011; Anneken et al., 2015; Moszczynska \& Callan, 2017; Partama et al., 2018).

Various therapeutic targets have been developed to prevent or minimize the negative effects of methamphetamine use. Increased level of oxidative stress has been considered as a potential trigger for neurotoxicity hence the expected ability for the administration of antioxidants to prevent damages caused by free radicals. The administration of antioxidants before methamphetamine exposure is expected to provide protective effects and prevent further damages created by methamphetamine exposure (Gholipour, 2016; McDonnell-Dowling \& Kelly, 2017).

\section{Mechanism of Methamphetamine-Induced Neurotoxicity}

Neurotoxicity involves the central nervous system damage that might lead to complications and significant distress. It can be caused by neurotoxins, psychostimulants, or excessive use of drugs. Neurotoxic effects of methamphetamine have been correlated with the pattern and dose of usage. Severe neural damage might cause serious consequences including coma, paralysis, dementia, incoordination, and convulsion. Mild damage might lead to memory loss, disorders of communication and motor function, and concomitantly decreases the patient's quality of life (Kousik et al., 2014; Sharma et al., 2014). Methamphetamine affects brain functions hence the development of addiction and varied brain pathology. This psychostimulant could permeate the blood-brain barrier to become a serum protein and lead to a somewhat adverse effect on the brain's microenvironment, cell edema, and even neuronal death. The damage of the blood-brain barrier is the first stage leading to further processes of neurotoxicity (Sharma et al., 2014; Yadnya et al., 2016).

As a whole, several mechanisms are involved in the occurrence of methamphetamine neurotoxicity. Those include hyperthermia, oxidative stress, excitotoxicity, neuroinflammation, and other mechanisms such as microglial activation, blood-brain barrier dysfunction, and apoptotic pathway activation (Heinsleigh, 2017). Methamphetamine produces reactive oxygen species (ROS) such as $\mathrm{OH}^{-}$(hydroxyl radicals), $\mathrm{H}_{2} \mathrm{O}_{2}$ (hydrogen peroxide), and $\mathrm{O}^{-}$ (superoxide anion) due to the increased dopamine auto-oxidation. ROS increases oxidative stress markers like lipid peroxidase and activates protease that triggers the cascade of cell death. The concurrently occurring mitochondrial metabolism dysfunction also induces neurotoxicity through inhibitions of the Krebs cycle and the electron transport chain. Other neurotransmitters such as glutamate (the main excitation neuron) also play an important role in the occurrence of neurotoxicity. Glutamate accumulation causes $\mathrm{Ca}^{++}$influx leading to increased intracellular $\mathrm{Ca}^{++}$level. This high intracellular $\mathrm{Ca}^{++}$level triggers the intracellular cascade to activate protein kinase, phosphatase, NOS (nitrous oxide system) to produce NO, leading to endoplasmic reticulum stress and activation of the apoptotic pathway. Furthermore, the process of inflammation occurs, marked by the methamphetamine-induced activation of $\mathrm{NFKB}$, leading to the transcription of proinflammatory cytokines in the microglia. The result is the increased levels of IL-6, IL-1 $\beta$, TNF- $\alpha$, MCP-1, dan ICAM-1 (Yang et al., 2018).

\section{The Therapy of Methamphetamine-Induced Neurotoxicity}

Severe neurotoxicity induced by drugs or psychostimulants has been demonstrated in various studies. Efforts, as follow, have been attempted for developing neuroprotection from such damages (Sharma et al., 2014):

a) 5-HT receptor modulator

Psychostimulants induce hyperthermia by involving biogenic amine neurotransmitters. One potent biogenic amine that might be involved is 5-HT which affects the medication-induced body temperature regulation and modulates the release of other neurotransmitters through the receptor mechanism in the CNS. The serotonergic receptor has also been implied in the blood-brain barrier damage and edema. Serotonin receptor blockade inhibits the blood-brain barrier damage caused by various stressors and plays an important role in inhibiting the psychostimulant-induced neurotoxicity (Muller \& Homberg, 2014).

b) Antioxidant components

Increased oxidative stress has been proposed as one of the mechanisms leading to neurotoxicity due to the release of free radicals and lipid peroxidase. This state might damage the cell membrane and the blood-brain barrier, consequently leading to cell edema and damage. Several types of antioxidants have demonstrated protective effects from the process of neurotoxicity (Sharma, 2014). The administration of high dose amphetamine or methamphetamine increases free radicals, and antioxidant administration before the 
amphetamine exposure has led to the delay of amphetamine-induced dopaminergic deficit (Brown \& Yamamoto, 2003).

c) Neurotropic factors and its combination

The benefit of neurotrophic factors has been greatly studied in CNS trauma. The addition of exogenous neurotrophic factors, such as the combination of BDNF and GDNF, plays a role in inhibiting psychostimulant-induced neurotoxicity (Nikulina et al., 2014).

d) Nanodrug

The psychostimulant-induced neurotoxicity might be exacerbated by several factors including nanoparticles, environment temperature, hypertension, or diabetes. The administration of nano-drug is effective due to its quick, widespread, and high-level penetration into the CNS (Sharma et al., 2014).

\section{Anthocyanin as Neuroprotector}

Antioxidants are classified based on their molecular characteristics into enzymatic and nonenzymatic antioxidants. Based on their mechanism of action, antioxidants are grouped into primary and secondary antioxidants. Primary antioxidants search for free radicals and inhibit the oxidation through the chain reaction disruption. Normally they have reactive $\mathrm{OH}$ and $\mathrm{NH}$ that inhibit proton transfer to free radical species. Secondary antioxidants break hydroperoxide to stable non-radical products (Smetanska, 2018).

Flavonoid is one of the non-enzymatic antioxidants, and anthocyanin is a type of flavonoid. Other flavonoids and polyphenols have significantly contributed to the antioxidant activities within the body. Anthocyanin is a potent antioxidant found abundantly in fruits, vegetables, red wine, and purple sweet potato (Primayanti et al., 2012). Antioxidant properties of anthocyanin in the purple sweet potato has been demonstrated in mice, rats, and rabbits (Jawi et al., 2008; Jawi \& Budiasa, 2011; Jawi et al., 2012). Sweet potatoes decreased the plasma MDA level in rats with oxidative stress (Jawi et al., 2008). Another study has investigated the effect of anthocyanin from the purple sweet potato in the cerebellum of the ischaemic stroke rate model induced by the Middle Cerebral Artery Occlusion (MCAO) technique. The study showed that the sweet potato-derived anthocyanine increased the cerebellar BDNF level and VEGF expression in rats experiencing an ischemic stroke. This might justify its use as one therapeutic modality for ischaemic stroke (Rahmawati et al., 2018). The expression of cerebellar apoptotic cells of the rats with ischemic stroke decreased significantly $(\mathrm{p}<0.01)$ after 72 hours of reperfusion therapy with purple sweet potato anthocyanin (Tribuana Dewi et al., 2018). The daily dose of $3 \mathrm{ml}$ given for 7 days also increased the expression of Bcl-2 in the rat model experiencing an ischemic stroke. The potential mechanism proposed is the increased production of indigenous antioxidants and suppressed formation of malondialdehyde (Adnyana et al., 2018).

Baicalein, a flavonoid derivate taken from Scutellaria baicalensis root, has demonstrated an ability to inhibit DAT loss in the striatum caused by the methamphetamine-induced neurotoxicity. This shows the neuroprotective effect of baicalein. The proposed mechanism is by inhibiting lipid peroxidation and neutrophil ROS production (Wu et al., 2006). Pre-methamphetamine exposure intraperitoneal injection of isoliquiritigenin (ISL), another flavonoid with chalcone structure and active components from licorice (Glycyrrhiza radix), has significantly prevented methamphetamine-induced DAT and TH (tyrosine hydroxylase) reduction. ISL also suppresses methamphetamine-induced glial cell activation and inhibits nitric oxide synthase expression and NF- $\mathrm{KB}$ activation through blockade of phosphorylation (Lee et al., 2009). The neuroprotective effect of polyphenol of green tea has been demonstrated in the nigral dopamine neuron. Pretreatment with polyphenol (-)- epigallocatechin-3-gallate (EGCG) prevents the degeneration of dopamine neurons in the substantia nigra through its antioxidant activity. Interestingly, green tea polyphenol inhibits the $3 \mathrm{H}$-dopamine and 1-methyl-4- phenylpyridinium (MPP+) uptake, and protects the dopamine neurons from toxicity through the inhibition of the DAT activity (Chen et al., 2007).

The neuroprotective effect of the anthocyanin has been studied with the whisker cut rat model. The rats were exposed to psychological and emotional distress that subsequently started the oxidative stress in the tissue. They displayed increased protein carbonyl and lipid peroxidase in the brain, heart, kidney, and liver. The rats were then fed with $100 \mathrm{mg} / \mathrm{kg}$ body weight anthocyanin extracted from the Vaccinium myrtillis $L$ for 7 days. The administration of active anthocyanin in the brain depressed the stress-induced brain's oxidative stress and dopamine abnormalities (Rahman et al., 2008). Anthocyanin and phenolic compounds from the boysenberry and blackcurrant have demonstrated a significant protective effect and restored the capacity of calcium buffering of cells affected by the oxidative stress induced by dopamine and amyloid $\beta 25-35$ (Ghosh et al., 2007).

Anthocyanin containing food is a potentially effective neuroprotector candidate for preventing neuronal cell death reduction, and this compound works with various mechanisms (Li et al., 2017). One study has investigated the potential benefit of anthocyanin within the purple sweet potato (Ipomoea batatas L) extract provided to 35 smokers 
for 14 days. Significant differences $(\mathrm{p}<0.05)$ were found for plasma MDA and NOx levels among groups (the control group, $\mathrm{P} 1$ group that received $15 \mathrm{ml}$ purple sweet potato syrup, and $\mathrm{P} 2$ group that received $30 \mathrm{ml}$ purple sweet potato syrup). The plasma MDA level decrease was $35.39 \%$ and $49.87 \%$ in P1 and P2 group, respectively, while the plasma NOx level increase was $7.78 \%$ and $14.68 \%$ in P1 and P2, respectively (Primayanti et al., 2012). Anthocyanine within the purple sweet potato demonstrated stronger DPPH (1,1-diphenyl-2- picrylhydrazyl) radical finding activity than anthocyanine from red cabbage, grape peel, elderberry, or purple corn. Eight main components of anthocyanin within the purple sweet potato showed higher activity than ascorbic acid (Panda \& Sonkamble, 2012). Anthocyanin is also effective in decreasing ROS production induced by ethanol. Its activity as an antioxidant plays an important role in neuroprotection (Chen \& Luo, 2010).

Parkinson is a type of degenerative disease marked by the loss of dopaminergic neurons in the midbrain area. Anthocyanin from blueberry, grape seeds, and Chinese mulberry, significantly suppresses the rotenone that induces dopaminergic cell death through the activation of microglia and the mitochondrial repair dysfunction. Mitochondrial dysfunction could be caused by oxidative stress and this might initiate further neuronal damage (Li et al, 2017). Another example of antioxidants is vitamin $\mathrm{C}$ that could reduce the production of free radicals, maintain the glutathione homeostasis, and induce the expression of HO-1 (Yang et al., 2018).

Anthocyanin has demonstrated significant neuroprotective properties from apoptosis induced by mitochondrial oxidative stress (MOS), which is also effective as GSH (glutathione) in protecting the CGNs (cerebral granule neuron). Bcl-2 inhibition leads to a significant decrease in mitochondrial GSH and this process is prevented by anthocyanine (Kelsey et al., 2011).

Studies have been conducted to develop effective pharmacological strategies to manage methamphetamineinduced neurotoxicity. As described above, methamphetamine affects the dopamine reuptake and initiates dopamine oxidation. This initiates the production of ROS and RNS which would subsequently trigger the degeneration of dopaminergic terminals and neuronal apoptosis. This demonstrated that oxidative stress is one of the main mechanisms that play a role in methamphetamine-induced CNS damage. Pharmacotherapy with antioxidants could be administered to further explore effective strategies to protect neuronal cells from damages caused by methamphetamine-induced oxidative stress (Yang et al., 2018).

\section{Summary}

Many studies have been conducted to develop effective pharmacological strategies to manage methamphetamineinduced neurotoxicity. Methamphetamine initiates dopamine oxidation and the production of ROS and RNS, as one of the main mechanisms that play a role in methamphetamine-induced neurotoxicity. Antioxidants work by slowing, preventing, or eliminating oxidative stress in the target molecule, directly searching for reactive oxygen species (ROS), or by indirectly enhancing the antioxidant defense and inhibiting ROS production. Antioxidants bind with free radicals to form stable new radicals through an intramolecular hydrogen bond in the subsequent oxidation. Anthocyanin is arguably the most potent antioxidant within the flavonoid group. Several new studies have demonstrated that anthocyanin could play a neuroprotective role in cases of neurotoxicity. Pharmacotherapy with antioxidants could be administered to protect neuronal cells from damages caused by methamphetamine-induced neurotoxicity.

\section{References}

Adnyana, I. M. O., Sudewi, A. R., Samatra, D. P., \& Suprapta, D. N. (2018). Neuroprotective Effects of Purple Sweet Potato Balinese Cultivar in Wistar Rats With Ischemic Stroke. Open access Macedonian journal of medical sciences, 6(11), 1959. https://dx.doi.org/10.3889\%2Foamjms.2018.435

Allan, J. L., McMinn, D., \& Daly, M. (2016). A bidirectional relationship between executive function and health behavior: evidence, implications, and future directions. Frontiers in neuroscience, 10, 386. https://doi.org/10.3389/fnins.2016.00386

Anneken, J. H., Angoa-Pérez, M., Sati, G. C., Crich, D., \& Kuhn, D. M. (2017). Dissecting the influence of two structural substituents on the differential neurotoxic effects of acute methamphetamine and mephedrone treatment on dopamine nerve endings with the use of 4-methylmethamphetamine and methcathinone. Journal of Pharmacology and Experimental Therapeutics, 360(3), 417-423. https://doi.org/10.1124/jpet.116.237768

Brown, J. M., \& Yamamoto, B. K. (2003). Effects of amphetamines on mitochondrial function: role of free radicals and oxidative stress. Pharmacology \& therapeutics, 99(1), 45-53. https://doi.org/10.1016/S0163-7258(03)00052- 
4

Chen, G., \& Luo, J. (2010). Anthocyanins: are they beneficial in treating ethanol neurotoxicity?. Neurotoxicity research, 17(1), 91-101. https://doi.org/10.1007/s12640-009-9083-4

Chen, P. H., Huang, M. C., Lai, Y. C., Chen, P. Y., \& Liu, H. C. (2014). Serum brain-derived neurotrophic factor levels were reduced during methamphetamine early withdrawal. Addiction biology, 19(3), 482-485. https://doi.org/10.1111/j.1369-1600.2012.00444.x

Chen, X., \& Mao, S. S. (2007). Titanium dioxide nanomaterials: synthesis, properties, modifications, and applications. Chemical reviews, 107(7), 2891-2959.

Dewi, L. T., Adnyana, M. O., Mahdi, C., Prasetyawan, S., \& Srihardyastutie, A. (2018). Study of Antocyanins Activity from Purple Sweet Potato for Reducing Apoptotic Cells Expression of The Cerebellum On Ischemic Stroke Rats. The Journal of Pure and Applied Chemistry Research, 7(2), 94.

Dewi, N. N. A., \& Mustika, I. W. (2018). Nutrition content and antioxidant activity of black garlic. International Journal of Health Sciences, 2(1), 11-20. https://doi.org/10.29332/ijhs.v2n1.86

Dwi-Primayanti, I. D. A. I., Aman, I. G. M., \& Agus-Bagiada, N. (2012). Ipomoea batatas Syrup Decrease Malondialdehyde and Increase Nitrous Oxide Plasma Levels Amongst Moderate Smoker Workers at Denpasar. Medical faculty Udayana University. Bali Medical Journal, 3, 125-30.

Gholipour, F., Shams, J., \& Zahiroddin, A. (2017). Protective Effect of Coenzyme Q10 on MethamphetamineInduced Apoptosis in Adult Male Rats. Novelty in Biomedicine, 5(3), 127-132. https://doi.org/10.22037/nbm.v5i3.17397

Ghosh, D., McGhie, T. K., Fisher, D. R., \& Joseph, J. A. (2007). Cytoprotective effects of anthocyanins and other phenolic fractions of Boysenberry and blackcurrant on dopamine and amyloid $\beta$-induced oxidative stress in transfected COS-7 cells. Journal of the Science of Food and Agriculture, 87(11), 2061-2067. https://doi.org/10.1002/jsfa.2964

Heinsleigh, E. (2017). Review: Mechanisms of Methamphetamine Neurotoxicity. Journal of Pharmacology \& Clinical Toxicology, 5(5), 1087

Jawi, I. M., \& Budiasa, K. (2011). Ekstrak air umbi ubi jalar ungu menurunkan total kolesterol serta meningkatkan total antioksidan darah kelinci. Jurnal Veteriner, 12(2), 120-125.

Jawi, I. M., Suprapta, D. N., Dwi, S. U., \& Wiwiek, I. (2008). Ubi jalar ungu menurunkan kadar MDA dalam darah dan hati mencit setelah aktivitas fisik maksimal. Jurnal Veteriner Jurnal Kedokteran Hewan Indonesia, 9(2), 6572.

Jawi, I. M., Suprapta, D. N., Dwi, S. U., \& Wiwiek, I. (2008). Ubi jalar ungu menurunkan kadar MDA dalam darah dan hati mencit setelah aktivitas fisik maksimal. Jurnal Veteriner Jurnal Kedokteran Hewan Indonesia, 9(2), 6572.

Jawi, I., Sutirtayasa, I., Suprapta, D. N., \& Mahendra, A. N. (2012). Hypoglicemic and antioxidant activities of balinese purple sweet potato (Ipomoea batatas $\mathrm{L}$ ) in induced diabetic rat.

Kelsey, N., Hulick, W., Winter, A., Ross, E., \& Linseman, D. (2011). Neuroprotective effects of anthocyanins on apoptosis induced by mitochondrial oxidative stress. Nutritional neuroscience, 14(6), 249-259. https://doi.org/10.1179/1476830511Y.0000000020

Koob, G. F. (2009). Neurobiological substrates for the dark side of compulsivity in addiction. Neuropharmacology, 56, 18-31. https://doi.org/10.1016/j.neuropharm.2008.07.043

Koob, G. F. (2009). Neurobiological substrates for the dark side of compulsivity in addiction. Neuropharmacology, 56, 18-31. https://doi.org/10.1016/j.neuropharm.2008.07.043

Kousik, S. M., Napier, T. C., Ross, R. D., Sumner, D. R., \& Carvey, P. M. (2014). Dopamine receptors and the persistent neurovascular dysregulation induced by methamphetamine self-administration in rats. Journal of Pharmacology and Experimental Therapeutics, 351(2), 432-439. https://doi.org/10.1124/jpet.114.217802

Krasnova, I. N., Justinova, Z., \& Cadet, J. L. (2016). Methamphetamine addiction: involvement of CREB and neuroinflammatory signaling pathways. Psychopharmacology, 233(10),

1945-1962. https://doi.org/10.1007/s00213-016-4235-8

Lee, M. J., Yang, C. H., Jeon, J. P., \& Hwang, M. (2009). Protective effects of isoliquiritigenin against methamphetamine-induced neurotoxicity in mice. Journal of pharmacological sciences, 111(2), 216-220. https://doi.org/10.1254/jphs.09153SC

Li, D., Wang, P., Luo, Y., Zhao, M., \& Chen, F. (2017). Health benefits of anthocyanins and molecular mechanisms: Update from recent decade. Critical reviews in food science and nutrition, 57(8), 1729-1741. https://doi.org/10.1080/10408398.2015.1030064

Lu, R. B., Lee, S. Y., Wang, T. Y., Chang, Y. H., Chen, P. S., Yang, Y. K., .. \& Chen, S. L. (2017). Long-term heroin use was associated with the downregulation of systemic platelets, BDNF, and TGF- $\beta 1$, and it contributed 
to the disruption of executive function in Taiwanese Han Chinese. Drug and alcohol dependence, 179, 139-145. https://doi.org/10.1016/j.drugalcdep.2017.06.035

McDonnell-Dowling, K., \& P Kelly, J. (2017). The role of oxidative stress in methamphetamine-induced toxicity and sources of variation in the design of animal studies. Current neuropharmacology, 15(2), 300-314.

McFadden, L. M., \& Vieira-Brock, P. L. (2016). The Persistent Neurotoxic Effects of Methamphetamine on Dopaminergic and Serotonergic Markers in Male and Female Rats. Toxicology: open access, 2(2). https://dx.doi.org/10.4172\%2F2476-2067.1000116

Moszczynska, A., \& Callan, S. P. (2017). Molecular, behavioral, and physiological consequences of methamphetamine neurotoxicity: implications for treatment. Journal of Pharmacology and Experimental Therapeutics, 362(3), 474-488. https://doi.org/10.1124/jpet.116.238501

Moszczynska, A., \& Yamamoto, B. K. (2011). Methamphetamine oxidatively damages parkin and decreases the activity of $26 \mathrm{~S}$ proteasome in vivo. Journal of neurochemistry, 116(6), 1005-1017. https://doi.org/10.1111/j.1471-4159.2010.07147.x

Mueller, C. P., \& Homberg, J. R. (2015). The role of serotonin in drug use and addiction. Behavioural brain research, 277, 146-192. https://doi.org/10.1016/j.bbr.2014.04.007

Nikulina, E. M., Johnston, C. E., Wang, J., \& Hammer Jr, R. P. (2014). Neurotrophins in the ventral tegmental area: Role in social stress, mood disorders and drug abuse. Neuroscience, 282, 122-138. https://doi.org/10.1016/j.neuroscience.2014.05.028

Panda, V., \& Sonkamble, M. (2012). Phytochemical constituents and pharmacological activities of Ipomoea batatas 1.(Lam) - a review. International Journal of Research in Phytochemistry and Pharmacology, 2(1), 25-34.

Partama, I. B. G., Yadnya, T. G. B., Trisnadewi, A. A. A. S., \& Sukada, I. K. (2018). Increasing nutrition value of fermented rice hull through biofermentation of lactobacillus complex bacteria supplemented. International Journal of Life Sciences, 2(2), 73-82. https://doi.org/10.29332/ijls.v2n2.179

Rahman, MY (2008). The Process of Issuance of Location Determination in the Context of Land Procurement for Implementation of Development in the Public Interest in Kendal District (Doctoral dissertation, Semarang State University).

Salamanca, S. A., Sorrentino, E. E., Nosanchuk, J. D., \& Martinez, L. R. (2015). Impact of methamphetamine on infection and immunity. Frontiers in neuroscience, 8, 445. https://doi.org/10.3389/fnins.2014.00445

Sharma, H. S., Menon, P., Lafuente, J. V., Muresanu, D. F., Tian, Z. R., Patnaik, R., \& Sharma, A. (2014). Development of in vivo drug-induced neurotoxicity models. Expert opinion on drug metabolism \& toxicology, 10(12), 1637-1661. https://doi.org/10.1517/17425255.2014.970168

Smetanska, I. (2018). Sustainable production of polyphenols and antioxidants by plant in vitro cultures. Bioprocessing of Plant In Vitro Systems, 225-269. https://doi.org/10.1007/978-3-319-54600-1_2

Volkow, N. D., Koob, G., \& Baler, R. (2015). Biomarkers in substance use disorders. ACS chemical neuroscience, 6(4), 522-525. https://doi.org/10.1021/acschemneuro.5b00067

Wati, E. R., Prasetyawan, S., Mahdi, C., Srihardyastutie, A., \& Adnyana, M. O. (2018). Potential of Anthocyanin From Purple Sweet Potato (Ipomoea batatas) To Increase BDNF Level and VEGF Expression in The Cerebellum of Ischemic Stroke Rats. The Journal of Pure and Applied Chemistry Research, 7(1), 45. https://doi.org/10.21776/ub.jpacr.2018.007.01.363

Wu, P. H., Shen, Y. C., Wang, Y. H., Chi, C. W., \& Yen, J. C. (2006). Baicalein attenuates methamphetamineinduced loss of dopamine transporter in mouse striatum. Toxicology, 226(2-3), 238-245. https://doi.org/10.1016/j.tox.2006.06.015

Yadnya, T. B., Trisnadewi, A. A., Sukada, I. K., \& Oka, I. G. L. (2016). The effect of fermented purple sweet potato (ipomoea batatas 1) skin in diets on feed and anthocyanin consumption, carcass characteristics, anthioxidant profile and meat texture of Bali duck. International Research Journal of Engineering, IT \& Scientific Research, 2(9), 73-80.

Yamada, K. I. Y. O. F. U. M. I. (2008). Pro-addictive and anti-addictive factors for drug dependence. Nagoya J Med Sci, 70, 67-72.

Yang, X., Wang, Y., Li, Q., Zhong, Y., Chen, L., Du, Y., ... \& Yan, J. (2018). The main molecular mechanisms underlying methamphetamine-induced neurotoxicity and implications for pharmacological treatment. Frontiers in molecular neuroscience, 11 , 186. https://doi.org/10.3389/fnmol.2018.00186 